\title{
loT business models in an industrial context
}

\section{Review Article}

Author(s):

Weinberger, Markus; Bilgeri, Dominik; Fleisch, Elgar (D)

Publication date:

2016-09-13

Permanent link:

https://doi.org/10.3929/ethz-b-000120964

Rights / license:

In Copyright - Non-Commercial Use Permitted

\section{Originally published in:}

at - Automatisierungstechnik 64(9), https://doi.org/10.1515/auto-2016-0054 


\title{
Übersicht
}

\section{Markus Weinberger, Dominik Bilgeri*, and Elgar Fleisch IoT business models in an industrial context}

\author{
IoT Geschäftsmodelle im Industrie Kontext
}

DOI 10.1515/auto-2016-0054

Received March 29, 2016; accepted April 29, 2016

\begin{abstract}
There is a broad consensus that the transformative power of the Internet of Things (IoT) will affect all kinds of industries; or, to put it in a more optimistic light, that almost no domain is excluded from the opportunities to leverage the IoT. But, what does this mean for the future of industrial processes? This article introduces the concept of high-resolution management (HRM). IoT enables the collection of high-resolution data for the physical world where, as in the digital world, every aspect of business operations can be measured in real-time. This capability facilitates high-resolution management, such as short optimization cycles in industrial production, logistics and equipment efficiency, comparable to methods like A/B-Testing or Search Engine Optimization, which are state of the art in digital business. We take the following two perspectives on leveraging high-resolution management. First, through greater insights into their industrial processes, companies that apply HRM in their operations are able to achieve higher efficiency, quality and flexibility. The example of vehicle fleet management illustrates this effect. Second, we build upon the St. Gallen Business Model Navigator in order to look in greater detail on how the IoT affects industrial processes. Gassmann et al. ${ }^{1}$ in troduce 55 generic business model patterns, of which our
\end{abstract}

Article Note: This research paper is mainly based on the following prior publications $[10,11,29]$, while at the same time introducing new use case examples.

1 Gassmann, O., Frankenberger, K., and Csik, M. (2014). The business model navigator: 55 models that will revolutionise your business. Financial Times.

*Corresponding author: Dominik Bilgeri, ETH Zurich, 8092 Zurich, Switzerland, e-mail: dbilgeri@ethz.ch

Markus Weinberger: Bosch Software Innovation GmbH, Bosch IoT Lab, Dufourstrasse 40a, 9000 St. Gallen, Switzerland Elgar Fleisch: University of St. Gallen, Dufourstrasse 40a, 9000 St. Gallen, Switzerland; and ETH Zurich, 8092 Zurich, Switzerland

extended research identified 20 that could profit significantly from the IoT ${ }^{2}$. Analyzing these 20 patterns allowed for the identification of six key components: Remote Usage and Condition Monitoring, Object Self Service, Digital Addon, Digital Lock-in, Product as a Point of Sales and Physical Freemium. These building blocks help companies to supply HRM-supported offerings. Finally, the example of remote monitoring of process parameters shows that these business model components can also be deployed to create offerings that enable others to apply HRM.

Keywords: Internet of Things, Industry 4.0, high resolution management, business models.

Zusammenfassung: Dieser Artikel befasst sich mit dem Konzept des „High Resolution Managements“ (HRM). Das „Internet der Dinge“ (IoT), die Vision einer zunehmenden Verschmelzung der physischen mit der digitalen Welt, spielt dabei eine entscheidende Rolle. Neue Sensor- und Aktuator-Technologien ermöglichen Unternehmen Daten in unbekannter Detailschärfe auszuwerten. Die vorliegende Arbeit betrachtet das Konzept des „High Resolution Managements" aus zwei unterschiedlichen Perspektiven: Einerseits wird die Hypothese ausgearbeitet, dass die neu gewonnene Fülle an Daten Unternehmen erlauben wird, ihre Prozesse effizienter, flexibler und qualitativ hochwertiger zu gestalten. Andererseits stellt sich die Frage, wie das Internet der Dinge Geschäftsmodelle im Industriekontext beeinflussen wird. Aufbauend auf den 55 Geschäftsmodellmustern von Gassmann et al. ${ }^{3}$, werden aus fortführender Forschung sechs Kernkomponenten von IoT Geschäftsmodellen präsentiert: Remote Usage and Condition Monitoring, Object Self Service, Digital Add-on, Digital Lock-in, Product as a Point of Sales und Physical Freemium.

2 Fleisch, E., Weinberger, M., and Wortmann, F. (2014). Geschäftsmodelle im Internet der Dinge. HMD Praxis der Wirtschaftsinformatik, 51(6), 812-826; Gassmann, O., Frankenberger, K., and Csik, M. (2014). The business model navigator: 55 models that will revolutionise your business. Financial Times. 
Schlüsselwörter: Internet der Dinge, Industrie 4.0, Geschäftsmodelle.

\section{Introduction}

The Internet of Things is currently an omnipresent vision. This is true for the academic publication landscape, the agendas of executives as well as industry trade fairs like the most recent CeBIT 2016 in Hannover. The term was initially coined at the Auto-ID labs at the Massachusetts Institute of Technology (MIT) and describes the vision that virtually all objects become smart and connected $[2,18]$. Thereby, a special focus lies on the efforts to achieve smart, connected and automated production facilities and manufacturing systems [3,11]. In Germany this digitalization of the industry is often referred to using the term "Industry 4.0" in line with the identically named initiative of the German Federal Ministry of Education and Research [4]. The paper at hand aims to offer a framework for practitioners and scholars alike how to structure the potential influence of the Internet of Things on companies across various sectors. Organizations can make use of the IoT in three different ways:

(1) apply IoT-generated, high resolution data to improve internal and external processes,

(2) enrich their product portfolio with sensor and actuator technologies to offer so called digitally charged products, or

(3) supply IoT technologies to enable others to become successful players in the IoT ecosystem themselves.

The first role, applying high resolution management (HRM), enables companies to increase the efficiency, quality and flexibility of their internal processes as well as improve their customer and supplier relationship management [11]. Regarding the second role, providing digitally charged products, IoT technologies allow companies to either offer entirely new solutions, enhance the value propositions of existing offerings or to target new customer segments [10]. The third role, when becoming an IoT enabler, companies again equip other players with the necessary IoT tools or capabilities to either apply HRM or provide digitally charged products.

This paper argues that for either role (or a combination out of the three) a clear understanding of the concept of high resolution management is crucial for a company's long-term success. Only if companies master both the technical as well as economic IoT related challenges, they will benefit from digitalization [10]. The remainder of this paper is structured as follows. The next section offers an in- troduction to the Internet of Things in general and Industry 4.0 in particular. Section 3 then elaborates on the new means of high resolution data collection enabled through IoT technologies and the deriving managerial opportunities. Section 4 describes how to leverage high resolution management from two different perspectives. A brief conclusion in Section 5 offers final remarks.

\section{IoT and the Industry 4.0}

The Internet of Things, a term initially coined at the AutoID labs at the Massachusetts Institute of Technology (MIT), describes the vision that virtually all objects become smart and connected $[2,18]$. This implies that objects become capable of communicating with each other, the Internet and humans - either directly or via medium devices such as smartphones [11]. As a consequence, the digitalization trend or to be more specific new IoT sensor and actuator technologies are going to merge the two previously separated worlds: the physical and the digital world [11]. Figure 1 below illustrating this merger graphically, also displays the five value layers of a generic IoT solution.

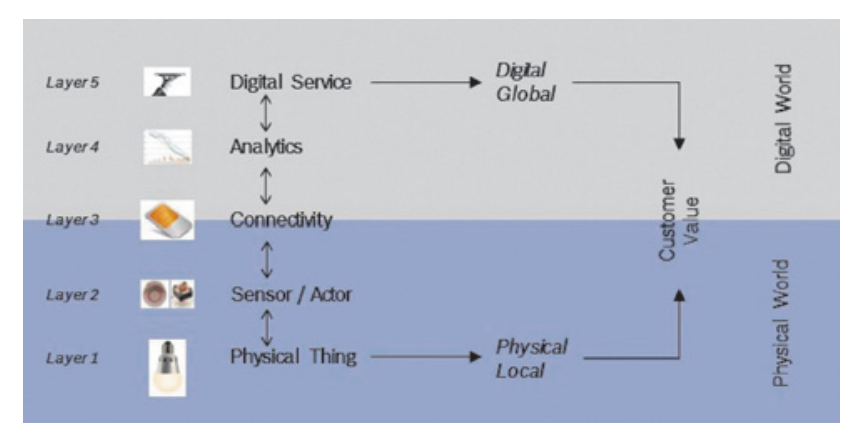

Figure 1: Five value layers of an IoT solution (Fleisch et al., 2014).

The physical thing (layer 1) refers to the object itself and the local customer value it offers. An example could be a common light bulb, simply spending light without offering any other functionality. Since the physical thing is bound to a specific location the local part of the value proposition is so, too.

If this common light bulb in a next step would be equipped with IoT technologies, such as motion detection sensors or actuators enabling flash light warnings (layer 2), this will increase the value proposition of the offering. Nevertheless the new functionalities could still only be used on a local level.

Not until adding connectivity (layer 3), either by using telecommunication providers or using in-house network 
structures, will the application be accessible and able to communicate to the online word. As highlighted by Green, McCarson and Devine [14], at this layer it is important to decide how much computing actually takes place within the device compared to the cloud or a back-end.

However, simply connecting smart devices per se does not add any further value. Hence, data analytics (layer 4) are required. Properly analyzing large amounts of data can be challenging and requires a broad skill set from checking and structuring data, to combining collected data with information from various other sources [19].

In a final layer, using the output of all previous layers together, digital services (layer 5) can be offered to add customer value on a global level. In the case of a connected light bulb such a service could include a warning system that notifies its users with a smartphone message, in case some intruder should be detected. An additional service could be a "pretending to be at home" simulation mode, where the smart light bulb learns about residents' movements and "plays" that sequence, when the house is empty [8]. Such digital services are usually offered and made accessible in location-independent, packaged and suitable formats, using mobile apps or web tools [10]. Overall it is important to realize that rather than only combining single layers, successful IoT solutions require an integration of all five value layers.

The IoT has the potential to affect almost all life situations and will most probably be a game changer in the majority of B2C as well as B2B industries [20]. While it enables a broad field of applications, especially in Germany cyber-physical production systems (CPPS) recently gained specific attention [22]. Thereby, the German government as well as industry leaders see the "industry on the threshold of the fourth industrial revolution” [22, p. 767]. This fourth industrial revolution, or to put it differently, the digitalization of the industry, aims to enable a series of new opportunities to save costs and improve outputs. Some of the most popular attempts include preventive maintenance, remote control, manufacturing analytic tools and services, management of process quality as well as smart retrofitting of machinery [5]. Additionally, beyond the focal company's borders, Industry 4.0 technologies, will allow to integrate whole supply chains, tracking and tracing inter and intra plant logistics. Summarizing all these emerging possibilities, Usländer and Epple [27, p. 860] describe Industry 4.0 systems as "distributed processing systems [that overcome] vertical (e.g. across the layers of the automation pyramid) and horizontal system boundaries (e.g. across organizations)”.

\section{High resolution management}

The fourth industrial revolution, as part of the general trend towards an Internet of Things, significantly reduces transactions costs, caused by real world vs. virtual world media breaks [11]. The reduction of media breaks itself is not new, also previous technological inventions aimed to decrease their number. For instance, department-wide information systems in accounting replaced troublesome manual procedures where accounting clerks transferred information from paper sheets into electronic calculators and vice versa. In a next step, company-wide enterprise resource planning (ERP) systems and subsequently crosscompany information systems, e.g. supply chain management systems, again allowed companies to avoid millions of media breaks [11].

But why has it since long been a critical target to reduce media breaks in companies anyway? Humans, despite their various skills and merits are in general not proficient in dealing with media breaks [11]. This causes three main issues for companies. First, media breaks are errorprone, because humans usually fail to replicate boring, simple and tiring tasks (e.g. continuously typing in numbers) all day. Since the average data accuracy can be as low as $70 \%$, this is a severe problem [9] that causes additional efforts and costs. Second, media breaks involving humans are slow, as humans are not capable of processing a lot of data simultaneously (cf. [26]). Lastly, media breaks are costly. Either because they cause errors as indicated above, or more generally, because in the long run engaging labor is more expansive, than investing into automated machines fulfilling the same tasks [11].

While in fact, every data entry method introduced so far, including keyboards, voice control or barcodes helped to reduce media breaks and thus transaction costs [23], the IoT is bringing the continuous efforts to minimize the number of media breaks to a totally new level. In a world where virtually every object is equipped with some sort of minicomputer, sensor or actuator the parameter "transaction costs" converges towards zero [11]. This development makes high-resolution data becoming economically viable. Referring to a company's data collection behavior this means that based on reduced costs the amount of data collected and the degree of detail increases significantly. According to Fleisch [11, p. 16] across industries and applications "the movement from low-resolution sensing to high resolution sensing" can be observed along the three axis time, data and place.

Time - since in the physical world it is usually very costly and complicated to collect data, companies rarely perform data collections. A good example is the classical 


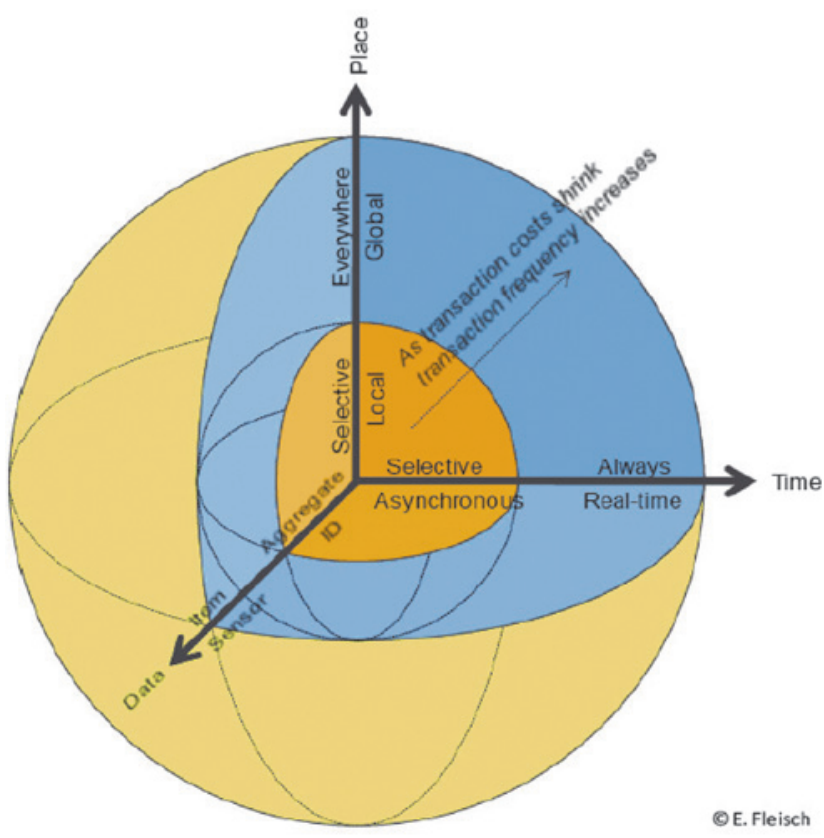

Figure 2: Towards real world high resolution data (Fleisch 2010).

warehouse inventory, which was usually used to be performed once a year only [12]. IoT technologies will allow to collect real-time data at marginal costs of almost zero.

Data - in addition to shorter intervals also the richness of data increases with decreasing sensing costs. Small and cost-efficient sensors will be capable of reporting various object-related as well as environmental parameters. A concrete use case example is "TraQ", a smart delivery box, capable of exchanging a variety of parameters with other cyber-physical systems along the production process. TraQ is currently developed as part of a conjoint Industry 4.0 project of the Robert Bosch GmbH in Stuttgart and the Fraunhofer Institute for Material Flow and Logistics IML in Dortmund [28].

Place - using IoT sensor and actuator technologies, it becomes economical to not just gather data related to in-house processes but to cover the entire value chain. Thereby, new geo-tracking and connectivity standards, such as LTE, G4 and GPS/GSM technology, allow for location-independent data collection worldwide.

With this shift from previously selective and low resolution data towards real-time, high resolution data, displayed in Figure 2, also a change of management practices can be pursued. Peter Drucker, one of the leading management thinkers of the last century once stated, "You can't manage what you can't measure" [19]. In line with this statement, "measuring the effects of a system is a condition of being able to understand and improve it." [11, p. 17]. In a world, where smart things are constantly communi- cating and generating a rich hidden data pool, managers will be equipped with new means to keep track of their companies' processes, customer segments, user behavior, employee performance as well as future supply and demand changes in real time. In addition, HRM capabilities will facilitate best practice management techniques, such as short optimization cycles in industrial production, logistics and equipment efficiency, comparable to methods like A/B-Testing or Search Engine Optimization, which are state of the art in digital business.

\section{Two perspectives how to leverage HRM}

Emerging IoT sensor and actuator technologies build the foundation of the fourth industrial revolution ("Industry 4.0") and allow companies to leverage new data insights in three different ways. First, through greater insights into their industrial processes, companies that apply HRM in their operations are able to achieve higher efficiency, quality and flexibility (referring to the first IoT role "high resolution management"). Second, IoT and thus HRM-supported business model components help companies to supply new and innovative offerings (referring to the second IoT role "provider of digitally charged products"). Third, the example of remote monitoring of process parameters shows that these business model components can also be deployed to create offerings that enable others to apply HRM (referring to the third IoT role "enabler"). This paper focuses on the first and second of the three company roles emerging in the IoT.

\subsection{Higher efficiency, quality \& flexibility}

High resolution management as described above allows companies to gain insights into their industrial processes to an extent unknown so far [31]. This enables organizations to increase the efficiency of their operations, while reducing waste and idle time [11]. In addition, organizations are able to further improve single production steps as well as the overall product quality. Finally, companies are expected to be much more flexible in planning their operations based on empirical data, automated retrofitting and a larger portfolio of connected and compatible machinery and power tools [7]. The example of vehicle fleet management at Bosch illustrates these effects of HRM.

Bosch, a leading German automotive supplier, currently offers an automobile fleet management system, 
allowing fleet operators to make use of a variety of new opportunities with regards to the analyses of individuals' driving behavior, single vehicle conditions or overall fleet productivity. With high resolution data, Bosch enables its customers (i.e. the fleet operators) to manage their fleets more precisely, since they are able to detect potential complications and problems already in advance. These early warnings in combination with the introduction of realtime counter-measures, increases the reaction time of fleet operators and helps to reduce costs.

Referring to Figure 1, and the five value layers within the IoT, the Bosch fleet management solution consists of various components spanning across value layers of both the physical and digital world. The connectivity control unit (CCU, value layer 2 in Figure 1) describes a Bosch device that is built in the respective vehicles (layer 1). This control device is connected to the car-internal control network and in addition possesses own sensors, such as a GPS sensor to detect the vehicle's geo-location. The collected data is transmitted via a mobile network (layer 3 ) to a backend provided by Bosch (i.e. a Bosch server infrastructure). There the transmitted data is coded and documented in databases in order to be analyzed and further processed (layer 4). In a next step the data pool is building the foundation for various digital services (layer 5) such as remote diagnostics, maintenance or fleet control [6].

The Dutch fleet operator "Leaseplan" with a fleet of 1.5 million vehicles under contract, uses the Bosch fleet management system and is a specific use case for the above described technology [30]. The example of the Bosch fleet management system, although only shading light on a single use case, provides interesting insights, illustrating how HRM allows fleet operators to manage their fleets more efficiently, while also being able to discriminate between customer segments. Looking at the classical business model of fleet operators, the mileage of their vehicles is a crucial indicator to determine the residual value of the company's main assets [15]. Traditionally in the majority of leasing contracts, thus a limited vehicle run time is determined for a specific leasing period (cf. [21]). However, in the light of missing data sources, fleet operators often lacked the possibilities to measure this important parameter during the leasing period. So far, fleet operators were only occasionally able to gain information on a car's mileage, for instance when vehicles have been inspected [29]. Referring to an IoT enabled fleet management system, as outlined above, now real-time data about all vehicles' mileage states are sent automatically to the backend after each trip. This allows fleet operators to detect high mileages far earlier and to avoid the exceedance of the contractual upper limit much more efficiently.

\subsection{IoT specific BM components}

Besides enabling companies to improve their internal operations, high resolution management offers the opportunity to apply new business models. Initially arising in the 1990s, the term "business model" still lacks a common definition [32]. Broadly defined the term refers to "the rationale of how an organization creates, delivers and captures value" [24, p. 14]. In practice this rationale behind a company's business activities is often analyzed using conceptual representations such as the Osterwalder business model canvas (cf. [24]). At the same time, business models are often associated with the names of specific companies, like for instance McDonalds representing the franchise-model or the computer manufacturer Dell referring to the direct sales model [10]. Beyond such individual company examples, more generic business model patterns describe elements used in business models across various industries and companies.

Based on their comprehensive research, investigating over 300 companies, Gassmann etal. [13] introduce 55 generic business model patterns. In an extended research Fleisch etal. [10] build upon the findings of Gassmann et al. [13] and select 20 out of the 55 patterns that could profit significantly from the IoT [10]. Again, analyzing these 20 patterns in greater detail allowed for the identification of six key components inherent to these 20 patterns: Digital Add-on, Digital Lock-in, Product as a Point of Sales, Physical Freemium, Object Self Service as well as Remote Usage and Condition Monitoring [10]. These business model components describe how companies could supply HRM-supported offerings. While it is not possible to elaborate on all 20 IoT specific business model patterns, the six newly identified business model components inherent to these 20 patterns will be described in greater detail below.

Digital Add-on describes a business model component, where various digital services are offered in the after-sales phase of a physical good. A prominent and recent example is provided by the electronic car manufacturer Tesla, who offered an autopilot software update for $\$ 2,500$ [25]. This digital add-on can be bought by owners of the newer Tesla car generation and enables their vehicles to park automatically. In the future it might be possible to buy other similar (also temporary) services, like for instance the opportunity to buy some additional 50 horsepower over the weekend to master a certain mountainous route.

Digital Lock-in refers to the well-known Razor and Blade business model pattern, deriving from the popular example of Gillette with its razors and the related blades. 
The business model component "digital lock-in" emphasizes that only original parts are compatible with the system. The IoT with its sensor and actuator technologies will enable entirely new means to limit compatibility of system-parts, to avoid counterfeits and to manage guarantees.

Product as a Point of Sales envisions how physical products can become platforms for digital sales and marketing services. An early (rather rudimentary) version of this business model component that already exists today, is the option to access an internet shop when pointing with a smartphone on a specific product. This allows companies to advertise or cross-sell further offerings directly via the original product. Additionally, by this means customers might collect loyalty points or search for user information applying any medium device, such as smartphones.

Physical Freemium stands for solutions, where a physical good is sold, along with a free digital service. Examples would be free digital maintenance or remote control services. Such services enhance the value proposition of the product and might allow companies to sell the physical product at a premium. However it is free for customers to use the basic service itself. In a next step some customers might decide to buy some extended, but charged services.

Object Self Service describes a scenario where not humans but machines reorder spare parts or required ingredients. An illustrative example could be a heating system automatically re-ordering oil as soon as a pre-defined threshold in the oil tank is reached. A more concrete example is the recently launched Amazon initiative "amazon dash replenishment service". It offers the option that selected household appliances (e.g. washing machines, printers) automatically reorder the required ingredients when necessary [1].

Remote Usage and Condition Monitoring finally refers to how smart offerings are capable of reporting real-time data about their own condition or the environment surrounding them. This allows companies to detect errors and potential problems in advance, control for the correct usage of the equipment and offer affordable and efficient maintenance. The example below outlines in greater detail how Konecranes used this business model component.

Konecranes, a leading manufacturer and provider of cranes and lifting equipment based in Finland, offers interesting insights, how HRM allows for the implementation of new business model components on the basis of new IoT technologies. In 2015 Konecranes introduced a new business model, allowing customers to rent industrial cranes in Finland and the UK for their general manufacturing customer segments. Claiming to have launched an industry-first rental solution, the company is targeting to generate new business through offering its customers a novel way of financing the investment [16]. Thus, Konecranes is addressing customers that weren't in their scope earlier. Konecrane RENTALL, how the solution is advertised, offers an all-inclusive leasing model with a leasing period of at least 36 month for a fixed monthly fee. The bundle includes the crane supply, a maintenance and service plan with periodic inspections, spare parts and consumables as well as an option to monitor cranes remotely [17].

Offering customers an all-inclusive leasing contract, just charging the actual hours the equipment was used, is not entirely new. The classical "power by the hour" business model pattern, initially launched by Rolls-Royce for its turbines is already well established. Nevertheless, in the case of Konecranes, only new sensor-collected data allowed the company to lease their cranes. This new rental business model for industrial lifting equipment is only possible due to the rich amount of data Konecranes could gather about its customers and their usage behavior of cranes. A broad set of crane usage parameters (runtime, starts, working cycles, overloads etc.) could be used to optimize the maintenance accordingly and improve the safety of operations. The examination and analyses of this data are part of Konecranes' competitive advantage and enable this new business model in the first place.

\section{Conclusion}

In this paper the managerial possibilities arising from high-resolution data as well as two perspectives on how to leverage them were highlighted. Most certainly, high resolution management (HRM) is going to provide companies with competitive advantages and will play a critical role in conducting a successful IoT business. At the same time organizations will be facing severe obstacles when implementing Industry 4.0 projects. As this article tried to highlight a critical task includes the choice of an organization's position in the IoT ecosystem, as well as the identification of challenges specifically related to that position. Outlining the three different IoT roles (i.e. high resolution management, digitally charged products and enabler) covered in this paper could offer a guiding framework for companies to choose a role, or combination of roles, to pursue. Despite these first insights, the research on HRM is still in an early stage and many research questions currently remain unsolved. This paper aimed to provide practitioners and scholars alike with food for thoughts introducing one 
approach how to structure and tackle companies' potential roles in an IoT context.

\section{References}

1. Amazon (2016). Amazon dash replenishment. Accessed on March 7, 2016. https://www.amazon.com/oc/dashreplenishment-service

2. Atzori, L., lera, A., and Morabito, G. (2010). The internet of things: A survey. Computer Networks 54(15), 2787-805.

3. Bauernhansl, T. (2014). Die Vierte Industrielle Revolution Der Weg in ein wertschaffendes Produktionsparadigma. In T. Bauernhansl, M. ten Hompel and B. Vogel-Heuser (Eds.), Industrie 4.0 in Produktion, Automatisierung und Logistik (p. 5-35). Springer Vieweg, 2014.

4. BMBF (2016). Digitale Wirtschaft und Gesellschaft - Zukunftsprojekt Industrie 4.0. Accessed on February 4, 2016. https:// www.bmbf.de/de/zukunftsprojekt-industrie-4-0-848.html

5. Bosch (2016a). Industrie 4.0: Intelligente Lösungen für die vernetzte Fertigung. Accessed on March 10, 2016. https://www.bosch-si.com/de/loesungen/fertigungsindustrie/ industrie-4-0/industrie-4-0.html

6. Bosch (2016b). Bosch vernetztes Flottenmanagement. Accessed on March 7, 2016. http://www.boschconnectedvehicle. com/de/bosch-vernetztes-flottenmanagement/

7. Bosch Software Innovations (2015). Marktstudie Industrie 4.0: Bedarf und Nutzen vernetzter Softwarelösungen. Accessed on March 10, 2016. https://www.bosch-si.com/media/de/bosch_ software_innovations/media_landingpages/market_survey_ industry_4_0/20150928_industry4_0_market_study_en.pdf

8. Comfylight (2016). Das lernende Licht, das auf dein Zuhause aufpasst. Accessed on March 14, 2016. http://www.comfylight.com/\#

9. DeHoratius, N., and Raman, A. (2008). Inventory Record Inaccuracy: An Empirical Analysis. Management Science, 54(4), 627-641.

10. Fleisch, E., Weinberger, M., and Wortmann, F. (2014). Geschäftsmodelle im Internet der Dinge. HMD Praxis der Wirtschaftsinformatik, 51(6), 812-826.

11. Fleisch, E. (2010). What is the Internet of Things? An Economic Perspective. Auto-ID Labs White Paper, University of St. Gallen.

12. Gabler (2016). Definition von Inventur. Accessed on March 5, 2016. http://wirtschaftslexikon.gabler.de /Definition/ inventur.html

13. Gassmann, O., Frankenberger, K., and Csik, M. (2014). The business model navigator: 55 models that will revolutionise your business. Financial Times.

14. Green, J., McCarson, B., and Devine, M. (2014). Building the Internet of Things. Accessed on March 12, 2016. https://daue6ehqissah.cloudfront.net/breakouts/2014/ H-ARC-01_Cisco-Intel-IBM_FINAL.pdf

15. Hughes, T., Liu, Z., and Castro, P. (2015). Residual Car Values Forecasting Using AutoCycle ${ }^{\mathrm{TM}}$. Moody's Analytics. Accessed on March 10, 2016. https://www.economy.com/getlocal? $q=4 b 5013$ c0-755b-4a79-8539-0718ea64f47d\&app=eccafile
16. Konecranes (2015a). Konecranes launch industry-first rental solution in UK. Accessed on February 20, 2016. http://www.konecranes.co.uk/resources/media/releases/ 2015/konecranes-launch-industry-first-rental-solution-in-uk

17. Konecranes (2015b). Konecranes RENTALL Solutions. Accessed on March 3, 2016. http://www.konecranes.co.uk/sites/ default/files/download/konecranes_rentall_brochure.pdf

18. Mattern, F., and Floerkemeier, C. (2010). Vom Internet der Computer zum Internet der Dinge. Informatik-Spektrum, 33(2), 107-121.

19. McAfee, A., and Brynjolfsson, E. (2012). Big data. The management revolution. Harvard Business Review, 90(10), 61-68.

20. Miorandi, D., Sicari, S., De Pellegrini, F., and Chlamtac, I. (2012). Internet of things: Vision, applications and research challenges. Ad Hoc Networks, 10(7), 1497-1516.

21. Mobilease (2016). Leasing 101: How to navigate the leasing jargon. Accessed on February 23, 2016. http://www.mobilease.com/leasing-101/

22. Monostori, L. (2015). Cyber-physical production systems: roots from manufacturing science and technology. at - Automatisierungstechnik, 63(10), 766-776.

23. Nooteboom, B. (1992). Information technology, transaction costs and the decision to 'make or buy'. Technology Analysis and Strategic Management, 4(4), 339-350.

24. Osterwalder, A., and Pigneur, Y. (2010). Business Model Generation: A handbook for visionaries, game changers, and challengers. (1st ed.). Hoboken, NJ: Wiley.

25. Porter, M. E., and Heppelmann, J. E. (2015). How Smart, Connected Products Are Transforming Companies. Harvard Business Review, 93(10), 96-114.

26. Shao, D. H., and Shao, L. P. (2012). The effects of multitasking on individual's task performance. Journal of International Business Strategy, 12(1), 75-80.

27. Usländer, T., and Epple, U. (2015). Reference model of Industrie 4.0 service architectures. at - Automatisierungstechnik, 63(10), 858-866.

28. von Janczewski, B. (2016). Bosch und Fraunhofer lassen das Internet der Dinge Wirklichkeit werden. Pressemitteilung. Accessed on March 18, 2016. http://www.iml.fraunhofer.de/ de/presse_medien/pressemitteilungen/bosch-undfraunhofer-lassen-internet-der-dinge-wirklichkeit-werd.html

29. Weinberger, M., Bilgeri, D., and Fleisch, E. (2016). Bosch Flottenmanagement: Das IoT fordert die Organisation. In O. Gassmann and P. Sutter (Eds.). Führen der Digitalen Transformation. Hanser Verlag, forthcoming.

30. Wimmelbücker, S. (2015). Flottenmanagement: VW verkauft Beteiligung an LeasePlan. In Automobilewoche Accessed on March 15, 2016. http://www.automobilwoche.de/article/ 20150723/NACHRICHTEN/150729978/flottenmanagement-vwverkauft-beteiligung-an-leaseplan\#.VgUrekZrNp1

31. Winter, J. S. (2014). Surveillance in ubiquitous network societies: Normative conflicts related to the consumer in-store supermarket experience in the context of the internet of things. Ethics and Information Technology, 16(1), 27-41.

32. Zott, C., Amit, R., and Massa, L. (2011). The business model: recent developments and future re-search. Journal of management, 37(4), 1019-1042. 


\section{Bionotes}

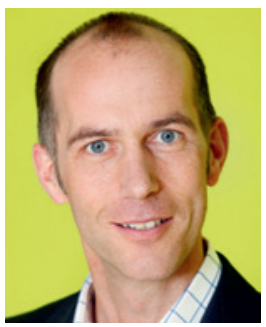

\section{Dr. Markus Weinberger}

Bosch Software Innovation $\mathrm{GmbH}$, Bosch IoT Lab, Dufourstrasse 40a, 9000 St. Gallen, Switzerland

Markus.Weinberger@bosch-si.com

Markus Weinberger is Director of the Bosch loT Lab at the University of St. Gallen. His work is focused on IoT applications in the domains of "Smart Home" and "Connected Mobility", as well as on IoT business models. Markus holds a PhD from TU Munich.

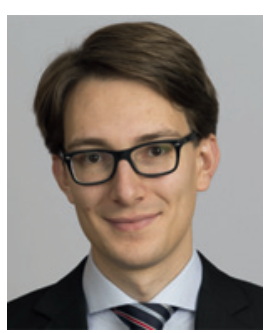

\section{Dominik Bilgeri, M.Sc.}

ETH Zurich, 8092 Zurich, Switzerland

dbilgeri@ethz.ch

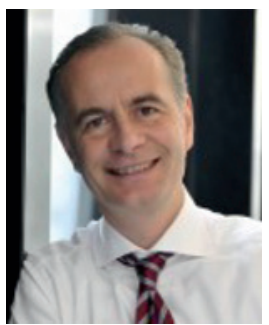

Prof. Dr. Elgar Fleisch

University of St. Gallen, Dufourstrasse 40a, 9000 St. Gallen, Switzerland; and ETH Zurich, 8092 Zurich, Switzerland elgar.fleisch@unisg.ch

Elgar Fleisch has a double appointment at ETH Zürich and University St. Gallen (HSG). At ETH, he is a full professor of information management, at HSG of technology management. In his research, Elgar Fleisch and his team aim at understanding and designing the ongoing merge between the physical and digital world. Elgar Fleisch is a co-founder of several university spin-offs and he serves as a member of multiple management boards and academic steering committees.

Dominik Bilgeri is a PhD candidate at the Bosch loT Lab of the Swiss Federal Institute of Technology in Zurich where he investigates the phenomenon of digital business models in the loT context. Dominik holds an MSc from Erasmus University Rotterdam. 